\title{
Attitudes and Behaviors of Egyptians Towards E-Payment Services
}

\author{
Alexander Chen \\ University of Central Arkansas
}

\author{
Jacob Walker \\ University of Central Arkansas
}

\author{
David McCalman \\ University of Central Arkansas
}
Sayed EISayed Elkhouly
Ain Shams University
Mohamed AbdEIDayem
Ain Shams University

\begin{abstract}
Because of the increasing prevalence of e-payment services across the globe, it is vital to understand what affects how and to what extent people utilize them. A survey was distributed to students and staff at Ain Shams University in Cairo, Egypt. Theoretically, the TAM model, TRA model, and social norms play a role in technology adoption. Most of the survey results are found to be consistent with those of western societies. Specifically, six constructs relating to adoption and four demographic backgrounds were tested. Usage was measured by three questions. A bivariate analysis indicates all constructs, i.e., incentive, perceived usefulness, perceived ease of use, social influence, perceived risk, and perceived trust, are significant. Regarding demographic variables, it is also found that age, working status, education, and gender relate to e-payment usage. However, gender and perceived usefulness are most important from the multivariate analysis. Since the study was conducted in a university environment and in English, a larger, more diverse sample is recommended for further research in Egypt.
\end{abstract}

Keywords: e-payment, Egypt, TAM, TRA, perceived usefulness, perceived ease of use

\section{INTRODUCTION}

In a quickly modernizing global economy, the ability to facilitate a fast, easy, and secure exchange of money is crucial for developing countries to catch up with developed nations, fight corruption, and increase economic prosperity. Egypt is in the middle of transitioning from a heavily cash-based society to one that utilizes e-payment systems. Even with the current systems provided by the Egyptian government, the internet infrastructure, website user-friendliness, and integration with the banking sector are found to be 
severely lacking (El Gohary, 2019). Many Arab countries still have a strong preference for cash as the primary form of payment. Egypt has the highest rate, with 70\% of Egyptian consumers preferring cash on delivery (G4S Global Cash Solutions, 2018). Making e-payment services available and increasing their adoption leads to an increase in consumption, access to credit (which can be used to increase personal capital like purchasing a home or founding a business), and transaction efficiency (Zandi, 2013). Egypt also has a severe corruption crisis. It is estimated that Egypt has lost up to \$57.2 billion USD due to financial crime between 2000-2008 (Danziger, 2011). Implementing e-payment systems in Nigeria showed that the added security and efficiency reduced fraud and finance-related crimes (Aliyu, 2020). Government procurement of electronic services in order to "increase transparency, accountability, real-time access to information, and increase competition among bidders", which includes the adoption of e-payment systems, inevitably reduces corruption (Neupane et al., 2012). When small businesses have access to e-payment, transparency increases - which reduces corruption - and revenue collection becomes more efficient (Wambua, 2017). Kiambu county in Kenya saw a 60\% increase in revenue collected because of the "automation of revenue collection" (Strathmore University, 2017). The Vice President of Banque Misr, Akef el Maghrabi, commented, "When you eliminate or reduce the reliance on cash, then you fight corruption, you provide convenience, you lower costs, and you grow the economy" (International Finance Corporation, 2019). If Egypt is to experience the full benefits of the unprecedented period of economic growth and global interconnectedness of the last decade, the adoption of an electronic financial system might play a decisive role. The Egyptian government has already taken steps in 2018 to work towards a robust e-payment economy with Decree No. 760, which says "all payments of all governmental dues, including tax and customs in excess of one hundred thousand pounds, will be through electronic payment and collection system" (Youssry Saleh Law Firm, 2020). The Egyptian government also seeks to stabilize the Egyptian pound, which is inflating at roughly 7\% per year (O'Neill, 2021), to combat increasing incentives for citizens to adopt foreign currencies and engage in black market trade, particularly with decentralized cryptocurrency. This will work hand-in-hand with Egypt's relatively free movement of capital and labor, which Egypt actually ranks higher in than the United States according to the Fraser Institute's Economic Freedom of the World report, in addition to centralized collective bargaining and minimum wage laws (Fraser Institute, 2020).

The rise of information and communication technology on economic growth and development is widely supported (Bahrini and Qaffas, 2019; Sen and Saray, 2020) and is of particular relevance with regard to the infrastructure in place for the digitization of commerce (Yushi and Borojo, 2019; Bui, Pham, Williamson, Mohebbi and Le, 2020). Research has found that the digitization of commerce is correlated with commercial and economic growth and benefits within both wealthy and developing economies (Myovella, Karacuka, and Haucap, 2020). Elucidating the rise of e-commerce services and their utilization can thus prove helpful in economic forecasting and policymaking.

This study will make an essential contribution to the analysis of the overall economy and consumption. The findings can inform help academicians and policymakers to better understand the antecedents of the adoption and usage of technologies that can directly impact economic development efforts. It may also help the Egyptian government to eliminate black market transactions and activities as well as increase tax revenues for the government. Further, it will help the Egyptian government to ease problems with corruption. The results, however, might be tentatively generalized to other countries as well.

In this paper, we will explore demographic variables and their relationship with e-payment behavior. Also, the six major constructs (incentive, perceived usefulness, perceived ease of use, social influence, perceived risk, and perceived trust) tested in various studies will be examined on Egyptian citizens. Four demographic variables (age, gender, working status, and educational background) will be checked. The methods used to collect, analyze, and summarize data will be explained, along with the results. Recommendations on how to further increase the adoption of e-payment by consumers and the government will follow. 


\section{REVIEW OF THE LITERATURE}

E-payment has many different definitions throughout the existing literature. E-payment can be defined as "an electronic value transfer of a payment from the payer to the recipient through an electronic payment mechanism... with a web-based user interface that allows customers to access, manage their bank accounts and transactions remotely" (Fatonah, 2018). Chen et al. defined e-payment as "the transfer of funds electronically from a payer to the payee through an e-payment platform which enables customers to remotely access and manage their financial transactions through an electronic network" (Liu et al., 2021; Chen et al., 2020; Chen et al., 2019; Nadler et al., 2019; Chen et al., 2018; and Jeffus et al., 2017).

\section{Theoretical Background}

The Technology Acceptance Model (TAM) provides the basis for this study and others conducted by Chen et al. (2018 and 2020) for applying the attitudes and perceptions of users toward e-payment services. The TAM model argues that technology adoption is based on perceived ease of use and perceived usefulness. Users are more likely to adopt new technology if they feel that the technology is easy to use and it is useful to them. The TAM is in turn, based on the Theory of Reasoned Action (TRA) developed by Fishbein and Ajzen (1975). TRA seeks to find the relationships between behavior and beliefs, attitudes, and subjective norms. According to TRA, individual behavior is determined by what they believe about the action they intend to perform, the preconceived attitudes they hold about it, and what the individual thinks people important to them would perceive that behavior. It assumes that individuals are both rational and self-interested; they will put forth conscious effort to evaluate consequences, change prior beliefs, and reflect on attitudes regarding specific behaviors such that they make decisions to act in their best interest. Attitude is defined as "an individual's positive or negative feelings about performing the target behavior" (Fishbein and Ajzen, 1975). Subjective norms are defined as "the person's perception that most people who are important to him think he should or should not perform the behavior in question" (Fishbein and Ajzen, 1975).

Fred Davis suggested that the TAM could assist in understanding what factors affect individuals' adoption or lack thereof of new technology. The most significant constructs that Davis tested were perceived usefulness and perceived ease of use, which supports the findings of this paper. Perceived usefulness is defined as "the degree to which a person believes that using a particular system would enhance his or her job performance". Perceived ease of use is defined as "the degree to which a person believes that using a particular system would be free of effort” (Davis, 1989). Davis' findings imply that perceived usefulness and perceived ease of use would influence the attitudes towards technology adoption, the influence of social norms on adoption, and the actual extent of adoption. All the constructs implemented in this study have existing literature supporting their role in encouraging e-payment adoption. Visa (2016) published a report stating that incentives for consumers work best when most transactions are made in cash and a strong shadow economy is present. A similar study in also conducted in Cairo (Mourad and Sherif, 2015) showed that ease of use, privacy/security concerns, and compatibility were key in fostering positive attitudes toward e-payment. Several researchers from universities in the United Arab Emirates and Jordan (Salloum et al., 2019) wrote that perceived benefit, performance expectancy, perceived security/privacy, and perceived risk have significant relationships with students' usage of e-payment services. Kar (2020), out of New Delhi, found that "factors like cost, usefulness, trust, credibility, social influence, information, privacy, and responsiveness" have a tremendous influence on the adoption of e-payment. A survey utilizing the TAM model in Vietnam and Taiwan supported these findings with perceived ease of use, perceived usefulness, perceived risk, and information, all having significant effects on e-payment adoption (Lin and Nguyen, 2011). In this study, we will examine six major constructs, i.e., perceived usefulness, perceived ease of use, incentive, perceived risk, perceived trust, and social influence. 


\section{Hypothesis Development \\ Incentives}

The existing literature supports the notion that incentives have a significant impact on people's intentions to adopt e-payment services, regardless of the amount offered, type of incentive, and length of promotion period (Zhao and Zhang, 2019). In Albania, Banka (2013) argues that incentives are important for spurring the adoption of e-payment. Factors affecting e-payment adoption on the consumer side would be financial literacy, cash rewards, and ease of use; on the merchant side, tax breaks/subsidies and ease of use. In addition, he suggests that government has a role to play in e-payment incentives by limiting cash transactions, providing informative media, and lowering legal barriers to adoption. Banka suggested that the results of his study could be applied to other countries with similar economic features (Banka, 2013). One study regarding the banking sector in Morocco suggested that investing in the alignment of incentives with employee output increases overall employee satisfaction (Lachheb et al., 2019), which would result in a significant impact on customer attitudes toward e-banking. It is, hence, logical that we hypothesize that incentives will have a positive impact on e-payment behavior.

\section{Perceived Usefulness}

Perceived usefulness is defined as how much a potential adopter believes they should use or not use an application to the extent they believe it will help them perform their job better (Davis, 1989). Applying sample data from university staff in Nigeria to the TAM model, Tella and Olasina found that a correlation existed between the perceived usefulness of e-payment systems to the intent to use them (Tella and Olasina, 2014). A study in Semarang showed that perceived usefulness had a mediating effect on the relationship of ease of use to intent to use and perceived security (Ardiansah et al., 2019). Rogers' textbook Diffusion of Innovations provides insight into how perceived usefulness affects technology adoption (Roger, 1995). The individual "becomes aware of an innovation," "forms a favorable/unfavorable attitude toward" it, "engages in activities" leading to adoption or rejection, implements it, and "evaluates the results" (Orr, 2003). Following the TAM model and empirical studies, we hypothesize that perceived usefulness has a positive impact on e-payment behavior.

\section{Perceived Ease of Use}

Perceived ease of use is defined as how many potential adopters believe that an application is too hard to use and that the performance benefits of usage are outweighed by the effort required to use it (Davis 1989). The same study in Nigeria revealed the correlation between perceived ease of use and the intent to use e-banking system (Tella and Olasina, 2014). A model made using data from West Bengal explaining $69 \%$ of the variance in intention to use e-payment found that perceived ease of use was the most significant predictor (Roy and Sinha 2014). Relieving consumer anxiety towards adopting new technologies, particularly e-payment services, would be to strip away as much complexity from offerings while providing clear guidelines and rules (Atteya, 2012). Research by Tella found that ease of use is not only significantly correlated with e-banking adoption but also with retaining customers, increasing firm reputation, perceived risk, and perceived trust (Tella, 2012). It is reasonable to hypothesize the perceived level of ease of use positively relates to e-payment adoption.

\section{Social Influence}

Social influence is defined as the degree of susceptibility to suggestion through interpersonal relationships an individual experiences that affect their attitudes, perceptions, and beliefs (Bearden et al. 1989). A survey of e-money users in Indonesia found that social influence plays a significant role in epayment adoption; merchants and small business owners need more information and assurance, which is spread through word of mouth (Khatimah et al., 2019). A Korean study found a positive relationship between social influence and e-payment adoption; in this study, social influence was largely dependent on word of mouth and advertising as the means of transmission (Jeon and Ha 2010). Research on factors contributing to students' intent to adopt e-payment systems at the Universiti Putra Malaysia showed a positively significant relationship between intent to use e-payment and subjective norms, meaning that 
potential users are easily affected by people with whom they have close relationships (Jusoh and Jing 2019). Recent studies have identified social influences that affect e-payment adoption (Baby and Kannammal, 2020; Gong et al., 2020; Mousakket, 2020). Thus, we hypothesize a positive relationship between social influence and e-payment adoption.

\section{Perceived Risk}

Perceived risk is defined as "a combination of uncertainty" about a product or service "plus the seriousness of [the] outcome involved" in its usage (Baur, 1960). A study of Malaysian internet users demonstrated a strong, negatively significant impact on intention to adopt e-payment (Chin and Ahmad, 2013). A model based on 200 respondents in Ho Chi Minh City measuring perceived risk and trust accounted for 38\% of e-payment adoption (Nguyen and Huynh, 2018). A lower level of perceived risk has also been found to be statistically critical in intention to adopt an e-payment system (Xin et al., 2015; Teoh et al., 2013; Wang et al., 2003; Lee, 2009). Hence, we propose that perceived risk negatively affects epayment adoption behavior.

\section{Perceived Trust}

Millennial college students in Indonesia were shown to demonstrate that intent to use is more likely if there is a positive perception of ease of use and perceived usefulness, but once this perception is formalized, perceived security is a better predictor of usage (Ardiansah et al., 2019). A study by Barkhordari et al. on Iranians perceptions of trust and security show that trust is significantly influenced by access to security guidelines and overall security. At the same time, trust positively influences e-payment service adoption. They also recommend studying the influence of demographic factors on e-payment adoption for further research, which this study does (Barkhordari et al., 2017). Xin et al. describe how individuals' usage of epayment systems is affected by psychological traits and factors such as trust, disposition to trust, the perceived reputation of the provider, and uncertainty avoidance (Xin et al., 2015). Therefore, we hypothesize that perceived trust has a positive impact on e-payment adoption.

It is the expectation and hypothesis of the researchers that all constructs except perceived risk will be positively correlated with the overall adoption and usage of e-payment as well as the number of times used per month, the amount spent per month, and the percentage of monthly expenses paid via e-payment services. Perceived risk is hypothesized to have a negative correlation.

\section{METHODOLOGY}

In 2018-19, a survey was distributed to students and staff at Ain Shams University in Cairo, Egypt, by convenience sampling through email and social media. About 175 valid cases were collected. The survey instrument was constructed in English and not appropriate for Arabic-speaking only Egyptians. The survey instrument contained three sections. Section I (Attitudes and Perceptions) presented 7-point Likert scales for various questions about each of the six constructs. In this section, we adopted items used in Teoh et al. (2013). Section II (Usage) presented 5-point Likert scales asking how frequently participants used different devices, software, activities, and items for e-payment systems. They were also asked to what degree they use e-payment per month, how much they spend via e-payment per month, and what percentage of monthly expenses were paid through e-payment. Section III (Background) asked respondents about their age range, work status, student status, level of education, and biological sex. Overall, roughly an equal amount of both genders responded to the study. Most respondents $(n=134$ or $77 \%)$ were aged 26-50 (see Table 1). The average age was 37.27, with a standard deviation of 10.46. About $117(67 \%)$ of respondents work full-time, and roughly the same amount was either working part-time or unemployed, with a percentage around $15 \%$ each. The distribution of student status was found to be relatively equal, with $44 \%$ either part-time or fulltime students and $53 \%$ being university staff not enrolled in courses. Education attainment is relatively high in this sample, it was found that only $11 \%$ held an associate degree or were high school graduates, while $27 \%$ held a bachelor's degree and 58\% held a master's or doctorate degree. Since the sample was drawn 
from a university, substantial faculty and staff may account for the high proportion of respondents with a master's or higher education.

TABLE 1

DESCRIPTIVE STATISTICS FOR DEMOGRAPHIC VARIABLES

\begin{tabular}{|c|c|c|c|c|}
\hline Variables & Frequencies & Percentage & Mean & S.D. \\
\hline Gender & & & $.53^{*}$ & .50 \\
\hline Female & 90 & 51.4 & & \\
\hline Male & 80 & 45.7 & & \\
\hline Missing & 5 & 2.9 & & \\
\hline Total & 175 & 100 & & \\
\hline Age & & & $37.27 * *$ & 10.46 \\
\hline $18-20$ & 13 & 7.4 & & \\
\hline $21-25$ & 11 & 6.3 & & \\
\hline $26-30$ & 22 & 12.6 & & \\
\hline $31-35$ & 30 & 17.1 & & \\
\hline $36-40$ & 26 & 14.9 & & \\
\hline $41-45$ & 27 & 15.4 & & \\
\hline $46-50$ & 29 & 16.6 & & \\
\hline $51-55$ & 7 & 4.0 & & \\
\hline $56-60$ & 1 & .6 & & \\
\hline 61 and over & 4 & 2.3 & & \\
\hline Missing & 5 & 2.9 & & \\
\hline Total & 175 & 100 & & \\
\hline Work & & & $.77 *$ & .37 \\
\hline Full-Time & 117 & 66.9 & & \\
\hline Part-Time & 27 & 15.4 & & \\
\hline Unemployed & 26 & 14.9 & & \\
\hline Missing & 5 & 2.9 & & \\
\hline Total & 175 & 100 & & \\
\hline Student & & & $.29 *$ & .36 \\
\hline Full-Time & 22 & 12.6 & & \\
\hline Part-Time & 54 & 30.9 & & \\
\hline Non-Student & 93 & 53.1 & & \\
\hline Missing & 6 & 3.4 & & \\
\hline Total & 175 & 100 & & \\
\hline Education & & & $18.05^{* * *}$ & 2.61 \\
\hline High School & 12 & 6.9 & & \\
\hline Associates & 7 & 4.0 & & \\
\hline Bachelors & 48 & 27.4 & & \\
\hline Masters+ & 102 & 58.3 & & \\
\hline Missing & 6 & 3.4 & & \\
\hline Total & 175 & 100 & & \\
\hline
\end{tabular}

56 Journal of Organizational Psychology Vol. 21(5) 2021 
A Cronbach's Alpha analysis was conducted on the six major constructs using SPSS (see Table 2). Results showed that every construct was significant for Egyptian respondents, with the lowest alpha being .889 for incentives. The mean is relatively higher for incentives (with a mean of 5.55), perceived usefulness (with a mean of 5.48), and ease of use (with a mean of 5.63) - meaning that Egyptians value incentives to encourage utilization of e-payment services. The e-payment method has to be easy to use and very useful.

Social Influence was measured by multiple Likert Scale questions. In this measure, we asked users to rate on a seven-point scale their level of agreement or disagreement on the effect of the following influence sources: family, friends, colleagues, supervisors, IT professionals, government, mass media, and social media. The mean score of SI is found to be 4.31, which is closer to perceived risk and perceived trust, with 4.52 and 4.07 respectively. For Egyptians, according to our sample, incentives, ease of use, and usefulness are relatively more important than social influence, trust and risk.

TABLE 2

\section{CRONBACH ALPHAS AND DESCRIPTIVE ANALYSIS OF MAJOR CONSTRUCTS}

\begin{tabular}{lllll}
\hline & Items & Alpha's & Mean & S.D. \\
\hline INC & 5 & .889 & 5.55 & 1.48 \\
PU & 8 & .932 & 5.48 & 1.54 \\
EU & 6 & .940 & 5.63 & 1.62 \\
SI & 8 & .912 & 4.31 & 1.75 \\
PR & 6 & .912 & 4.01 & 1.70 \\
PT & 6 & .956 & 4.52 & 1.66 \\
USAGE & 3 & .838 & 4.07 & 1.87 \\
\hline
\end{tabular}

INC: Incentives

PU: Perceived Usefulness

EU: Perceived Ease of Use

SI: Social Influence (SI)

PR: Perceived Risk

PT: Perceived Trust

The usage is a composite variable. We used the ordinal coding of three dependent variables: frequency of monthly e-payment use, amount of money spent monthly, and percent of monthly expenditure via epayment. The Cronbach's Alpha was found to be .838 . We took the average of three ordinal values and made an additional measure of e-payment behavior that consists of all three aspects named "Usage" (see Table 2).

\section{RESULTS}

Three questions about Egyptian's usage of e-payment were asked: "How often do you use e-payment? Approximately __ times per month", "Approximately, how much money do you spend via e-payment per month? (in EGP)", and "Approximately, what percentage of your monthly expenses are paid via epayment?". About 55\% of respondents said they used e-payment 1-6 times per month, with $22.9 \%$ using it 1-2 times. On average, Egyptians are likely to engage in e-payment 5.32 times per week. The amount of money spent per month via e-payment varied, but more than 80\% spent less than 5,000 EGP (about 319 USD) per month. About a quarter spent between 201-800 EGP (about 13 - 51 USD) per month, and about a third spent between 1,200-5,000 EGP (about 77 to 319 USD). This suggests that e-payment is used rarely to purchase more expensive goods or services. Regarding monthly expenditure, it was found that 19 (or $10.9 \%$ ) of respondents did not spend any money via e-payment. For other spending categories, it was found that there was a fairly even distribution, i.e., of about 15 to 30 people in each category under 5,000 EGP. On average, Egyptian respondents spend 2,131.76 EGP (about 136 USD) with a standard deviation of 2,884.68 EGP (about 184 USD). The last measure of e-payment usage is the percent of monthly spending 
via e-payment. It was found that the largest group of Egyptians spend 1-10\%, and the second largest group spends $21-30 \%$ via e-payment. Most (140 or $80 \%$ ) respondents paid $40 \%$ or less of their monthly expenses via e-payment. On average, about $22 \%$ of their monthly spending was via e-payment.

TABLE 3

DESCRIPTIVE STATISTICS FOR DEPENDENT VARIABLES

\begin{tabular}{|c|c|c|c|c|}
\hline Variables & Frequencies & Percentage & Mean & S.D. \\
\hline Freq of Use & & & 5.32 & 4.32 \\
\hline 0 & 17 & 9.7 & & \\
\hline $1-2$ & 40 & 22.9 & & \\
\hline $3-4$ & 29 & 16.6 & & \\
\hline $5-6$ & 27 & 15.4 & & \\
\hline $7-8$ & 14 & 8.0 & & \\
\hline $9-10$ & 19 & 10.9 & & \\
\hline $11-12$ & 9 & 5.1 & & \\
\hline 13 and over & 13 & 7.4 & & \\
\hline Missing & 7 & 4.0 & & \\
\hline Total & 175 & 100 & & \\
\hline Money Spent & & & $2,131.76$ & $2,884.68$ \\
\hline 0 & 19 & 10.9 & & \\
\hline $1-200$ & 14 & 8.0 & & \\
\hline $201-400$ & 20 & 11.4 & & \\
\hline $401-800$ & 25 & 14.3 & & \\
\hline $801-1,200$ & 18 & 10.3 & & \\
\hline $1,201-2,500$ & 30 & 17.1 & & \\
\hline $2,501-5,000$ & 24 & 13.7 & & \\
\hline $5,001-8,000$ & 11 & 6.3 & & \\
\hline $8,001-12,000$ & 4 & 2.3 & & \\
\hline 12,001 and over & 5 & 2.9 & & \\
\hline Missing & 5 & 2.9 & & \\
\hline TOTAL & 175 & 100 & & \\
\hline Percent of Use & & & 21.84 & 20.04 \\
\hline $0 \%$ & 21 & 12.0 & & \\
\hline $1 \%-10 \%$ & 43 & 24.6 & & \\
\hline $11 \%-20 \%$ & 23 & 13.1 & & \\
\hline $21 \%-30 \%$ & 31 & 17.7 & & \\
\hline $31 \%-40 \%$ & 22 & 12.6 & & \\
\hline $41 \%-50 \%$ & 8 & 5.1 & & \\
\hline $51 \%-60 \%$ & 5 & 2.9 & & \\
\hline $61 \%-70 \%$ & 8 & 4.6 & & \\
\hline $71 \%-80 \%$ & 2 & 1.1 & & \\
\hline $81 \%-90 \%$ & 2 & 1.1 & & \\
\hline $91 \%-100 \%$ & 0 & 0 & & \\
\hline Missing & 9 & 5.1 & & \\
\hline TOTAL & 175 & 100 & & \\
\hline
\end{tabular}

Results for the bivariate analysis are shown in Table 4. Items 1-4 are dependent variables, including an overall usage variable representing the mean of the original three variables on usage. Items 5-8 are 
demographic variables. Items 9-14 are major constructs recommended via the literature. Both age and gender were not found to be statistically significant. All demographic variables are statistically significant with other measures of e-payment behavior. Age is positively correlated with all questions on usage except the percent of monthly expenses paid via e-payment. This means older respondents are more likely to use e-payment systems, specifically the weekly frequency and amount of money spent monthly. However, there is no age difference in the percentage of monthly spending. The monthly spending for Egyptians in this sample is about $22 \%$ (Table 3). Working status was also found to be statistically significant with e-payment adoption. People with full-time employment are more likely to use e-payment services than those who work part-time or are unemployed. Similarly, educational level was found to be positively related to e-payment adoption. People with higher educational attainment are more likely to use e-payment as a means of purchasing behavior. Notice that age, working status, and educational level are found to be highly correlated. Gender is also highly, but negatively, correlated with the first three dependent variables. This tells us that males are more likely to use e-payment overall, spend more money via e- payment, and pay their monthly expenses more frequently through e-payment. Like age, gender does not affect the percentage of monthly spending among respondents. Additionally, most demographic variables are correlated among themselves except gender. Gender was somewhat randomly distributed in this sample and was found to have no difference with age and education.

All six tested constructs were significantly correlated with usage measures. Incentives are related to all measures of e-payment adoption. Offering incentives to Egyptians was found to be one good way to promote e-payment behaviors. Those constructs proposed in the TAM or TRA model, i.e., perceived usefulness, perceived ease of use, perceived risk, perceived trust, and social influences, were found to be statistically significant for all different measures of e-payment. This confirms that most major constructs proposed for other parts of the world apply to Egyptian society. 


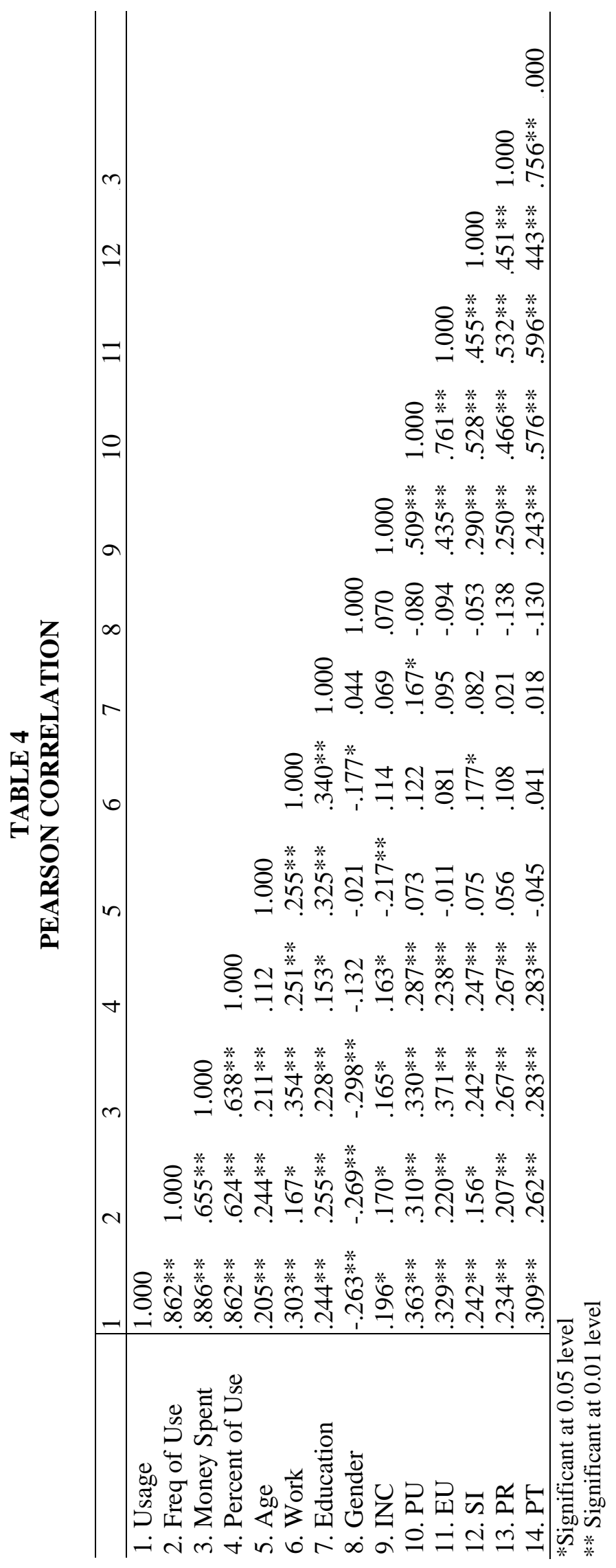


Since many independent variables are correlated, a stepwise regression can provide simple and clear ideas about the best predictors for the dependent variables. Table 5 presents the results of the stepwise regression. All the models were found to be statistically significant at the .000 level. The model for overall usage had an $R^{2}$ of .272, frequency of use had an $R^{2}$ of .243, money spent per month had an $R^{2}$ of .342, and percentage of monthly expenses paid had an $R^{2}$ of .144. These findings demonstrate that our models can explain anywhere between $14 \%$ and $34 \%$ of the variance of the dependent variables. Among four different models, it is clear that we have a better model in predicting the money spent per month (34\%) and a weaker model in predicting the percentage of monthly spending (14\%).

Regarding the parametric tests, there are two demographic variables identified, gender and working status. Gender had more impact on overall usage $(t=-3.484)$, the frequency of use $(t=-3.709)$ and money spent every month $(\mathrm{t}=-2.430)$, but gender was not statistically significant in predicting the percentage of monthly expenditure. Males are more likely to engage in e-payment from overall usage, frequency, and money spent perspectives. The amount of money spent per month was likely to be predicted by two demographic variables, gender and work status $(t=2.929)$. It is logical that the amount of money spent via e-payment is related to disposable income; in this case, the equation picked up the employment status. Other demographic variables are statistically important to dependent variables in the bivariate analysis, but because of the correlation with other independent variables, only gender and working status still remain significant in some of the stepwise regressions. Gender is found to affect overall usage, frequency, and the amount of money spent. For the money spent measure, the working status is also found to be important. For the percentage of monthly expenditure via e-payment, no demographic variables were identified.

For the other six constructs, perceived usefulness is relatively more important than other constructs. It is found that perceived usefulness positively explains total usage $(t=5.445)$, frequency of usage $(t=4.706)$ and percentage of monthly expenditure $(\mathrm{t}=2.290)$. For Egyptians, usefulness is one of the most import constructs that explain three out of four regression models. However, for the money spent, it is found that perceived usefulness is not important, but the ease of use is found to be in the predicting equation along with gender and working status. As mentioned before, no demographic variables predict the percent of use that is predicted by two constructs, perceived usefulness and perceived risk.

To simplify the predicting variables, it is recommended that gender and perceived usefulness are relatively more important factors that explain e-payment adoption in Egypt. Working status, ease of use, and risk are identified in one of the four regression models as also relatively important predictors.

TABLE 5

STEPWISE REGRESSION ANALYSIS

\begin{tabular}{|c|c|c|c|c|c|c|c|c|}
\hline & Usage & & Freq o & & Money & ent & Percen & Use \\
\hline & U.C. B & $t$ & U.C. B & $t$ & U.C. B & $t$ & U.C. B & $t$ \\
\hline Constant & 1.928 & 3.413 & 1.867 & 3.033 & .999 & .165 & 1.049 & 1.663 \\
\hline Work & & & & & 1.412 & $2.929 * *$ & & \\
\hline Gender & -1.000 & $-3.484 * *$ & -1.156 & $-3.709 * *$ & -.846 & $-2.430 *$ & & \\
\hline$P U$ & .508 & $5.445^{* *}$ & .479 & $4.706^{* *}$ & & & .273 & $2.290 *$ \\
\hline$E U$ & & & & & .628 & $5.985^{* *}$ & & \\
\hline$P R$ & & & & & & & .288 & $2.251 *$ \\
\hline$R$ Square & .272 & & .243 & & .342 & & .144 & \\
\hline$F$ & 23.200 & & 20.052 & & 21.848 & & 10.606 & \\
\hline Sig. & .000 & & .000 & & .000 & & .000 & \\
\hline
\end{tabular}

Legend: U.C. B = Unstandardized Coefficients B

Level of significance at $0.05=*$ and $0.01 * *$ 


\section{CONCLUSIONS}

Demographic variables were found to play significant roles in e-payment usage. Age was positively correlated with e-payment usage, which means older Egyptians are more likely to utilize e-payment. It is consistent with the previous studies in China, Japan, and Cote d'Ivoire, that age has a positive impact on epayment adoption. Typically, older people with higher income are more likely to expend money and use epayment systems. Gender was significantly correlated, meaning that being male is a stronger predictor of e-payment usage. Working status and educational level are also found to be statistically significant via a bivariate Pearson correlation. It also can be explained that people with full-time employment and higher education are more likely to earn a higher income, and thus are more likely to spend money and use an epayment system. Since most demographic variables are related, not all demographic variables were included in the stepwise regression. Gender was the major demographic variable in predicting e-payment behavior. The working status was also found to be a good predictor of how much money was spent on epayment. Relatively, demographic variables are not statistically important in predicting the percent spent via e-payment.

Similarly, all six theoretical constructs are highly correlated with e-payment usage. Egyptians did not seem to be different from those who use e-payment in other societies. Social influences from family, friends, peers, supervisors, experts, government, news media, or social media, are also important for e-payment adoption among Egyptians. Likewise, perceived ease of use, perceived risk, and perceived trust have been found to be important with all dependent measures via bivariate analysis. From stepwise regression models, we found the most powerful predictor for adoption was how useful Egyptians perceived e-payment to be for them. Relatively, the impacts from incentives, social influence, and perceived trust were found to be less important. Instead, perceived usefulness along with perceived ease of use and perceived risk were identified in four different stepwise regression models. Perceived usefulness is found to be good predictors in the three models. Perceived usefulness and perceived risk are two major factors in the percent of use model.

In sum, most demographic variables relate to e-payment measures, except that age and gender are not associated with percent of use. From the stepwise regression models, gender is found important in three models (it cannot predict the percent of use). In addition to gender, the working status is another demographic variable that is identified with the amount of money spent monthly. All six constructs are statistically associated with the dependent variables. In the stepwise regression analysis, it is found that perceived usefulness is a good predictor for three models with the exception of the money spent model. In money spent via e-payment, we found two demographic variables, gender and working status, as well as perceived ease of use to be good predictors. Two constructs, perceived usefulness and perceived risks, are two predictors found to be significant. In Egypt, if we want to predict e-payment behaviors, it is recommended to use gender and working status (for money spent only). For theoretical constructs, perceived usefulness is the most useful one with the exception of predicting money spent. In addition to perceived usefulness, perceived ease of use and perceived risk are also found to be statistical important in money spent or percent use models.

One downside of this study is the data set used in this paper. All respondents are academic staff, students, and professors. Egyptians employed in the academic field have the $4^{\text {th }}$ highest average monthly salary, which is almost double the average Egyptian's monthly salary (Middlebury Institute 2013). The lack of diversity is one weakness of this study.

This is a preliminary study on e-payment adoption behavior. Most of the results are compatible with the existing studies in this area. Since the sample is overly focused on academia and the English-speaking population, more diverse studies are recommended. 


\section{REFERENCES}

Adeyinka, T. (2014). Determinants of E-Payment Systems Success. International Journal of E-Adoption, 4, 15-38. doi:10.4018/jea.2012070102

Aliyu, O., Arasanmi, C., \& Ekundayo, S. (2020). Using Electronic Payment Programs as an AntiCorruption Strategy in Africa. doi:10.4018/978-1-7998-2398-8.ch007

Ardiansah, M., Chariri, A., Rahardja, S., \& Udin, U. (2020). The effect of electronic payments security on e-commerce consumer perception: An extended model of technology acceptance. Management Science Letters, 10(7), 1473-1480.

Ardiansah, M.N., Chariri, A., \& Januarti, I. (2019). Empirical study on customer perception of ecommerce: Mediating effect of electronic payment security. Jurnal Dinamika Akuntansi, 11(2), $122-131$.

Atteya, N.M. (2012). Role Stress Measure, Methods of Coping with Stress, and Job Performance: An Exploratory Study. Journal of Organizational Psychology, 12(2), 30-51.

Baby, A., \& Kannammal, A. (2020). Network Path Analysis for developing an enhanced TAM model: A user-centric e-learning perspective. Computers in Human Behavior, 107, 1-7.

Bahrini, R., \& Qaffas, A. (2019). Impact of information and communications technology on economic growth: Evidence from developing countries. Economies; Basel, 7(1), 1-13.

Banka, H. (2013). Incentives and mechanisms for boosting electronic payments: A case study of the Albanian payments landscape. Journal of Payments Strategy \& Systems, 7(3), 271-281.

Barkhordari, M., Nourollah, Z., Mashayekhi, H., Mashayekhi, Y., \& Ahangar, M.S. (2017). Factors influencing adoption of e-payment systems: An empirical study on Iranian customers. Information Systems and e-Business Management, 15(1), 89-116.

Bauer R.A. (1960). Consumer behavior as risk taking. In AMA Proceedings. Chicago.

Bearden, W., Netemeyer, R., \& Teel, J. (1989). Measurement of Consumer Susceptibility to Interpersonal Influence. Journal of Consumer Research, 15(4), 473-481. Retrieved March 7, 2021, from http://www.jstor.org/stable/2489543

Bui, N., Pham, L., Williamson, S., Mohebbi, C., \& Le, H. (2020). Intention to use mobile commerce: Evidence from emerging economies. International Journal of Enterprise Information Systems, $16(1), 1-9$.

Chen, A., Zeltmann, S., Griffin, K., Ota, M., \& Ozeki, R. (2020). Demographic background, perceptions, and e-payment usage among young Japanese. Global Journal of Business Disciplines, 4(1), 4-20.

Chen, A., Zeltmann, S., Griffin, K., Rubach, M., \& Ellis, M. (2019). Trends and Technology In EPayment. Competition Forum, 17(2), 388-398.

Chen, A.N., Nadler, S., Griffin, K., \& Derbe, J. (2018, July). Subjective Norms and Demographic Background on E-payment Behavior in Cote d'Ivoire. In Competition Forum (Vol. 16, No. 2, pp. 150-161). American Society for Competitiveness.

Chin, L.P., \& Ahmad, Z.A. (2013). Consumers Intention to Use a Single Platform E-Payment System: A Study Among Malaysian Internet and Mobile Banking Users. The Journal of Internet Banking and Commerce, 20(1), 1-13.

Chinho, L., \& Nguyen, C. (2011). Exploring e-payment adoption in Vietnam and Taiwan. Journal of Computer Information Systems, 51, 41-52.

Danziger, M.P. (2011, January 26). Egypt Lost \$57.2 Billion from 2000-2008. Global Financial Integrity. Retrieved from https://gfintegrity.org/press-release/egypt-lost-57-2-billion-2000-2008/

Davis, F. (1989). Perceived Usefulness, Perceived Ease of Use, and User Acceptance of Information Technology. MIS Quarterly, 13(3), 319-340. doi:10.2307/249008

Davis, F.D. (1989, September). Perceived usefulness, perceived ease of use, and user acceptance of information technology. MIS Q., 13(3), 319-340. https://doi.org/10.2307/249008

Economic Freedom of the World. (2020). Economic Freedom Rankings. Fraser Institute. Retrieved from https://www.fraserinstitute.org/economic-freedom/dataset?geozone=world\&min-year=2\&maxyear $=0 \&$ page $=$ dataset $\&$ filter $=0$ 
El Gohary, E. (2019). The Impact of Financial Technology on Facilitating E-Government Services: An Empirical Study on Egypt. Journal of Distribution Science, 17. doi:10.15722/jds.17.5.201905.51

Fatonah, S., Yulandari, A., \& Wibowo, F.W. (2018). A Review of E-Payment System in E-Commerce. Journal of Physics: Conference Series, 1140, 2. https://doi.org/10.1088/1742$6596 / 1140 / 1 / 012033$

Fishbein, M., \& Ajzen, I. (1975). Belief, Attitude, Intention, and Behavior: An Introduction to Theory and Research.

Gong, X., Zhang, K.Z.K., Chen, C., Cheung, C.M.K., \& Lee, M.K.O. (2020). Transition from web to mobile payment services: The triple effects of status quo inertia. International Journal of Information Management, 50, 310-324.

International Finance Corporation. (2019, November). Electronic Transactions Reshape Egypt's Economy. Retrieved from https://www.ifc.org/wps/wcm/connect/news_ext_content/ifc_external_ corporate_site/news+and+events/news/impact-stories/egypt-digital-payments

Jeffus, B., Griffin, K., Zeltmann, S., \& Chen, A. (2017). The Future of Mobile Electronic Payments. Journal of Competitiveness Studies, 25(3/4), 216-222.

Jeon, S-Y., \& Ha, K-S. (2010). 전자결제시스템의 수용에 미치는 영향요인 : 서비스품질.사회적 영향요인을 중심으로. 한국산학기술학회논문지, 11(9), 3239-3248. https://doi.org/10.5762/KAIS.2010.11.9.3239

Kar, A.K. (2020). What Affects Usage Satisfaction in Mobile Payments? Modelling User Generated Content to Develop the "Digital Service Usage Satisfaction Model." Information Systems Frontiers, 18. https://doi.org/10.1007/s10796-020-10045-0

Khatimah, H., Susanto, P., \& Abdullah, N.L. (2019). Hedonic motivation and social influence on behavioral intention of e-money: The role of payment habit as a mediator. International Journal of Entrepreneurship, 23(1), 1-9.

Lachheb, Y., Koubida, S., Yasin, M.M., \& Alavi, J. (2019). Employee Satisfaction in the Emerging Banking Sector of Morocco. Journal of Organizational Psychology, 19(3), 75-80.

Liu, M., Chen, A., \& Xue, J. (2021) Influencing Factors of E-Payment Behavior: An Empirical Study in Macau's Y And Z Generations. International Journal of Mobile Communications, forthcoming.

Md Jusoh, Z., \& Teng, Y.J. (2019). Perceived security, subjective norm, self-efficacy, intention, and actual usage towards e-payment among UPM students. Journal of Education and Social Sciences, $12(2), 8-22$.

Mouakket, S. (2020). Investigating the continuance usage intention of mobile payment: A multitheoretical perspective. International Journal of Mobile Communications, 18(6), 665-689.

Mourad, M., \& Sherif, H.F. (2015). E-payment Technology Adoption: Empirical Evidence From Emerging Economy. The 2015 WEI International Academic Conference Proceedings. Barcelona, Spain. Retrieved from https://www.westeastinstitute.com/wp-content/uploads/2015/02/MahaMourad.pdf

Myovella, G., Karacuka, M., \& Haucap, J. (2020). Digitalization and economic growth: A comparative analysis of Sub-Saharan Africa and OECD countries. Telecommunications Policy, 44(2), 1-11.

Nadler, S., Chen, A., \& Lin, S.F. (2019). E-Payment Usage among Young Urban Chinese. Journal of Business Diversity, 19(3), 75-88.

Neupane, A., Soar, J., Vaidya, K., \& Yong, J. (2012, August). Role of public e-procurement technology to reduce corruption in government procurement. In Proceedings of the 5th International Public Procurement Conference (IPPC5) (pp. 304-334). Public Procurement Research Center.

Nguyen, T.D., \& Huynh, P.A. (2018, January). The roles of perceived risk and trust on e-payment adoption. In International Econometric Conference of Vietnam (pp. 926-940). Springer, Cham.

O’Neill, A. (2021, March 31). Inflation rate in Egypt 2025. Statista. Retrieved from https://www.statista.com/statistics/377354/inflation-rate-in-egypt/

Orr, G. (2003, March). Diffusion of Innovations, by Everett Rogers (1995). Stanford University. Retrieved from https://web.stanford.edu/class/symbsys205/Diffusion\%20of\%20Innovations.htm 
Rogers, E. (1995). Diffusion of Innovations (4 ${ }^{\text {th }}$ ed.) New York: The Free Press.

Roy, S., \& Sinha, I. (2014). Determinants of Customers' Acceptance of Electronic Payment System in Indian Banking Sector - A Study. International Journal of Scientific \& Engineering Research, 5(1), 177. Retrieved from https://www.ijser.org/researchpaper/Determinants-of-CustomersAcceptance-of-Electronic-Payment.pdf

Salloum, S., Al-Emran, M., Khalaf, R., Habes, M., \& Shaalan, K. (2019). An Innovative Study of EPayment Systems Adoption in Higher Education: Theoretical Constructs and Empirical Analysis. International Journal of Interactive Mobile Technologies (iJIM), 13, 68-83. 10.3991/ijim.v13i06.9875

Sen, A., \& Saray, M.O. (2019). Information and communication technologies and economic growth: Evidence from EU and Turkey. Journal of Economic Cooperation and Development, 40(2), 169192.

Strathmore University. (2017, April 3). Counties go Tech in a Bid to Reach the Coveted Kshs. 50 Billion Target. Retrieved from https://www.strathmore.edu/news/counties-go-tech-in-a-bid-to-reach-thecoveted-kshs-50-billion-target/

Tella, A. (2012). Determinants of E-Payment System Success: A User's Satisfaction Perspective. International Journal of E-Adoption, 4(3), 15-38.

Tella, A., \& Olasina, G. (2014). Predicting Users' Continuance Intention Toward E-payment System: An Extension of the Technology Acceptance Model. International Journal of Information Systems and Social Change (IJISSC), 5(1), 47-67. doi:10.4018/ijissc.2014010104

The Middlebury Institute of International Studies. (2013). Average and Median Monthly Salary Comparison in Egypt. Retrieved from https://sites.miis.edu/educationinegypt/files/2013/05/CIEsalaryEgypt.pdf

Visa Inc. (2016). Perspectives on Accelerating Global Payment Acceptance. Retrieved from https://usa.visa.com/dam/VCOM/download/visa-everywhere/global-impact/perspectives-onaccelerating-global-payment-acceptance.pdf

Wambua, B.K. (2017). Adoption and Use of E-Payment in Revenue Collection by Machakos Town SubCounty Government for SMEs (Doctoral dissertation, University of Nairobi).

Wang, Y-S., Wang, Y-M., Lin, H-H., \& Tang, T-I. (2003). Determinants of user acceptance of Internet banking: An empirical study. International Journal of Service Industry Management, 14(5), 501519. https://doi.org/10.1108/09564230310500192

World Cash Report. (2018). World Cash Report 2018 (Rep.). G4S Global Cash Solutions. Retrieved February 11, 2021, from https://www.g4scashreport.com/

Xin, H., Techatassanasoontorn, A., \& Tan, F. (2015). Antecedents of Consumer Trust in Mobile Payment Adoption. Journal of Computer Information Systems, 55, 1-10.

Youssry Saleh Law Firm. (2020, April 2). Digital Payment and Collection Systems in Egypt- Youssry Saleh Law Firm. Retrieved from https://youssrysaleh.com/Investment-in-Egypt/the-start-ofdigital-payment-and-collection-systems-in-egypt/

Yushi, J., \& Borojo, D. (2019). The impacts of institutional quality and infrastructure on overall and intraAfrica trade. Economics, Kiel, 13(10), 1-34.

Zandi, M., Singh, V., \& Irving, J. (2013). The Impact of Electronic Payments on Economic Growth. Moody's Analytics. Retrieved from https://usa.visa.com/dam/VCOM/download/corporate/media/moodys-economy-white-paper-feb2013.pdf

Zhao, H., Anong, S.T., \& Zhang, L. (2019). Understanding the impact of financial incentives on NFC mobile payment adoption. International Journal of Bank Marketing. 